\author{
Zülfiye Acar Şentürk \\ Uşak University, zulfiyeacar@yahoo.com, Uşak-Turkey \\ Zühal Fidan \\ Mardin Artuklu University, zuhal fidan@hotmail.com, Mardin-Turkey
}

http://dx.doi.org/10.12739/NWSA.2016.11.2.3C0141

\title{
KURUMSAL SOSYAL SORUMLULUK UYGULAMALARINDA PAYDAŞ OLARAK KADIN: TÜRKIYYE VE AMERIKA'NIN EN DEĞERLİ 100 MARKASI ÜZERİNE KARŞILAŞTIRMALI BIR ARAŞTIRMA
}

Öz

Kurumsal Sosyal Sorumluluk (KSS) kuruluşlarla paydaşları arasında yapılmış bir niyet sözleşmesi gibidir. Kuruluşların paydaşlarıyla olan ilişkilerinin belirleyicilerinden olan sosyal sorumluluk faaliyetleri paydaşların ihtiyaç ve isteklerine göre belirlenip uygulanmaktadır. Paydaş olarak kadınların sorunlarının başında işsizlik, eşitsizlik, eğitimsizlik gelmektedir. Bu çalışmada Türkiye ve Amerika'nın en değerli 100 markasının web sayfalarındaki sosyal sorumluluk çalışmaları karşılaştırılmış ve sosyal sorumluluk çalışmalarında kadınlar için neler yapıldığı incelenmiştir. Amerikan markalarının çalışmaları daha çok girişimcilik alanında olurken; bunu sağlık alanındaki destekler izlemektedir. Türk markalarında sağlık ve spor yanında diğer alanlarda da az da olsa destek verilmektedir. Ayrıca Türk ve Amerikan markalarının bu alandaki sektörel dağılımında bankacılık ve telekomünikasyonun önde geldiği, hava yolu ve sigorta şirketlerinin ise son sıralarda yer aldığı sonucuna ulaşılmıştır.

Anahtar Kelimeler: Kurumsal Sosyal Sorumluluk Sosyal Sorumluluk, Kadın, Paydaş, Web Sayfası, Brand Finance 2015

WOMEN AS A STAKEHOLDER IN CORPORATE SOCIAL RESPONSIBILITY APPLICATIONS:
A COMPARATIVE STUDY ON 100 MOST VALUABLE BRANDS TURKEY AND AMERICA

\section{ABSTRACT}

Corporate social responsibility looks like a contract between organizations and their stakeholders. Corporate social responsibility (CSR) is one of determining factor in relationships between organizations and their stakeholders and it is planned and applied through stakeholders' needs and demands. As stakeholders, the most important problems of women are unemployment, inequality and scarcity of education opportunities. This study examines what kinds of activities were made for female stakeholders in corporate social responsibility works by comparing Turkey's and United States of America's 100 most valued companies' social responsibility activities on their web pages. The American brands have been most commonly working and getting support in the field of social responsibility entrepreneurship initiatives, followed by the support in the field of health. Turkish companies have been also supported in health, sport and some other sectors in minor level. The banking and telecommunications sectors take the first place with respect to distribution of Turkish and American brands in this area, and the airlines and the insurance companies locate in the last row.

Keywords: Corporate Social Responsibility, Social Responsibility, Woman, Stakeholder, Web Pages, Brand Finance 2015 


\section{GIRIŞ (INTRODUCTION)}

Baş döndürücü hızla ilerleyen teknoloji ile değişen ekonomik ve sosyal koşullar kuruluşların kullandıkları teknolojiden yönetim biçimlerine, paydaşları ile ilişkilerinden yaptıkları diğer faaliyetlere kadar birçok şeyin değişmesine de neden olmaktadır. Rekabet koşularının ve toplumun işletmelerden beklentilerinin değişmesi ile birlikte ne üretirsem satarım ya da ne yapsam beğenilir anlayışı yerini ne yaparsam topluma fayda sağlarım anlayışına bırakmıştır. Kuruluşların paydaşları ile ilişkilerinde önemli bir yeri olan kurumsal sosyal sorumluluk çalışmaları kuruluşların faaliyetlerine devam etmeleri için paydaşlardan aldıkları yetki olarak değerlendirilmektedir. Kuruluşların faaliyet gösterdikleri toplum yararına faaliyetlerde bulunmaları rekabet avantajı sağlamasının da ötesinde sadece kendi çıkarlarını değil bir şekilde iletişim halinde olduğu bireyleri, toplumu hatta içinde yaşadığımız dünyayı değerli bulduğu ve onun geleceği için yatırımlar yaptığı mesajı vermesi açısından önemlidir. Sosyal sorumluluğu, kuruluşların üretimden tüketime kadar olan faaliyetleri sürecinde onları topluma zararlı etkileri açısından sınırlayan, toplumun refahına katkıda bulunmaya zorlayan ve bunu öngören politikalar, prosedürler ve eylemlerin benimsenmesi olarak tanımlamak mümkündür (Boone ve Kurtz, 1992:73).

Archie Caroll'a göre sosyal sorumluluk dört bileşenden oluşmaktadır. Bunlar: Hissedarlar için kârlı olmak, çalışanlar için iyi istihdam olanakları yaratmak, müşteriler için kaliteli ürünler üretmek olan ekonomik sorumluluklar, kanunlara uymak ve oyunu kurallarına göre oynamak, plan yasal sorumluluklar, zarar vermeden, işi ahlakı göz önünde tutarak yürütmek; doğru, haklı ve adil olanı yapmak olan etik sorumluluklar ve topluma bir karşılık beklemeden katkılarda bulunmak, topluma yararlı işler için zaman ve para ayırmak hayırseverlik odaklı (philanthrophic) sorumluluklardır (Carroll, 1991:40-41). Bu bileşenlerden hangilerinin kimler için uygulanacağını ise kuruluşların paydaşları belirlemektedir. Kuruluşların faaliyet gösterdikleri sektörlere de bağlı olarak farklı farklı paydaşları vardır. (http://www.businessdictionary.com/) Kurumun faaliyetleriyle ilgilenen, kurumun faaliyetlerinden etkilenebilecekleri gibi bu faaliyetleri etkileyebilen kişi ya da kurumlar paydaşlar olarak tanımlanmaktadır.

Çalışanlar, müşteriler, yerel yönetimler, sivil toplum kuruluşları başta olmak üzere kuruluşların hizmetlerinde direkt ya da dolaylı olarak etkilenen herkes kuruluşun paydaşları olarak değerlendirilmektedir. Kuruluşlar sosyal sorumluluk faaliyetlerinde bu paydaş grubunun bir kısmını doğrudan etkileyecek çalışmalar yapmalarının yanında toplumun genelini ilgilendirecek uygulamalar da yapmaktadırlar. İşletmelerin toplumdaki rollerinin artmasına bağlı olarak faaliyet alanı içindeki paydaşlarının sayısı da artmaktadır. İsletmeler faaliyet alanlarına bağlı olarak çalışanlarına, müşterilerine, hissedarlarına ve faaliyet gösterdiği topluma karşı sorumludur, bu sorumluğun farkında olan kurumlar aldıkları kararlarla birçok yaşamını olumlu yönde değiştirebilmekte ya da bu gücü olumsuz biçimde değerlendirerek topluma zarar vermektedir. Sahip olunan güç kurumların paydaşlara karşı sorumluluklarını da artırmaktadır. Sahip olunan güç beraberinde sorumluluk almayı da getirmektedir (Evuleocha, 2005:333).

Toplumun ihtiyaçlarını ve beklentilerini karşılamak olarak da değerlendirilen sosyal sorumluluk çalışmaları ile bu ihtiyaçları karşılamayı ve toplumun gözünde daha iyi bir şekilde algı oluşturmayı amaçlayan kuruluşlar yaptıkları çalışmalarda sivil toplum kuruluşları ve devlet kuruluşları başta olmak üzere birçok ortakla birlikte 
çalışmaktadırlar. Kuruluşlar paydaş analizini doğru yaptıklarında ve paydaşların ihtiyaçlarını net bir şekilde tespit ettiklerinde yapılan sosyal sorumluluk çalışmaları amacına ulaşmakta ve destekçi bulmaktadır. Son zamanlarda dünyada ve ülkemizde kadın ya da toplumsal cinsiyet sorunları daha sık tartışılır olmuştur. Özellikle ülkemizde kadın cinayetleri, iş yerindeki eşitsizlikler, kadınların eğitimi ile ilgili tartışmalar birçok özel ve devlet kuruluşunu bu anlamda çalışmalar yapmaya yöneltmiştir. Kadınlara yönelik sosyal sorumluluk çalışmalarında daha çok kadınların iş sahibi olması ve kadına yönelik şiddeti önlemeye yönelik çalışmalar dikkati çekmektedir. Buna rağmen yapılan çalışmaların diğer alanlarda yapılan çalışmalara göre çok sınırlı alanda ve sınırlı sayıda yapıldığı görülmektedir. Bu çalışma ile kadınların paydaş olarak nasıl değerlendirildiği ele alınıp, sosyal sorumluluk çalışması yapmak isteyen kuruluşların dikkatinin konuya çekilmesi amaçlanmıştır.

\section{2. ÇALIŞMANIN ÖNEMI (RESEARCH SIGNIFICATION)}

Toplumdaki yeri ve sahip olduğu imkânlar çeşitli platformlarda ve her fırsatta tartışılan kadınlar, kimi zaman kendi imkânlarıyla kendileri için en iyiyi yapmanın mücadelesini verirken kimi zaman da kendilerine sunulan imkânlarla yaşama tutunma mücadelesi vermektedirler. Son yıllarda toplumda ayakta kalabilecek kadar yer bulmaya çalışan kadınların mücadelesi bazı kuruluşların dikkatini çekip bu kadınların desteklenmelerine neden olmuştur. Sosyal sorumluluk çalışmalarının ortaya çıkmasında etkili olan kadınlar bu çalışmalarda yeterince yer bulamamaktadırlar. Ülkemizde son zamanlarda yapılmış örnek çalışmalardan biri olan Kardelenler Projesi'nin kadınlara yönelik sosyal sorumluluk çalışmaları anlamında birçok kuruluşa örnek olduğunu söylemek mümkündür. Bu çalışmaların sürekli olması, kadınların insan haklarından kaynaklanan haklarına kavuşabilmeleri için daha fazla kuruluşun sosyal sorumluluk çalışmaları yapıp, daha iyi bir gelecek için onlara el uzatmaları gerekmektedir. Bu çalışma ülkemizde sosyal sorumluluk çalışmalarında kadının da paydaş olarak değerlendirilmesi gerektiğini ortaya koyması açısından dikkat çekicidir. Ayrıca Türkiye'nin itibarlı 100 şirketinin bu anlamda neler yaptığını değerlendirmesini yapan ilk çalışma olması nedeniyle önemlidir. Bir diğer önemi de Amerika'daki ilk 100 şirketin kadınlara yönelik olarak yaptığı sosyal sorumluluk çalışmalarının analiz edilerek sonuçların karşılaştırmalı olarak ele alınmasından kaynaklanmaktadır.

\section{LITERATÜR TARAMASI (LITERATURE REVIEW)}

3.1. Kurumsal Sosyal Sorumluluk (Corporate Social Responsibility)

Kurumsal Sosyal Sorumluluk (KSS) bir şirketin faaliyet gösterdiği yerdeki toplum ve çevreye karşı olan sorumluluk duygusudur. Şirketler bunu üretim sürecindeki kirliliği azaltarak, eğitim ve sosyal programlara katkı sağlayarak ve kullanılan kaynaklardan yeterli derecede kâr ederek göstermektedirler (www.businessdictionary.com). Avrupa Birliği kurumsal sosyal sorumluluğu kurumların toplum üzerinde etki bırakan sorumlulukları olarak tanımlamaktadır. Kurumlar topluma karşı sorumluluklarını; yasalara uyararak, işletme strateji ve uygulamalarında toplum, çevre, etik kurallar, müşterileri ve insan haklarını dikkate alarak yerine getirirler (http://ec.europa.eu). Kurumsal sosyal sorumluluk kavramının tarihi eskilere dayanmaktadır, belki de işin kendi tarihi kadar uzun bir tarihe sahiptir, buna rağmen kavram değişmeye devam etmektedir (Asongu, 2007:8).

Kavram dinamik bir yapıya sahip olduğu için ilişkili olan diğer yapıların sürekli değişim göstermesi kurumsal sosyal sorumluluğunda 
zaman ve koşullara bağlı olarak değişimini zorunlu kılmaktadır. Sosyal sorumluluk kavramı ile eş anlamlı olarak iş etiği, kurumsal vatandaşlık ya da sürdürülebilir gelişme gibi bir çok kavram kullanılmaktadır (Bolton vd., 2011:61-62).

Ayrıca kurumsal hayırseverlik kavramı olarak da tanımlanmakta, çevresel politikalarla da yoğun bir biçimde ilgili olduğu düşünülmekte ve kurumsal sosyal performans kavramı ile karıştırılmaktadır. Kavramın net bir tanımının yapılamaması sosyal sorumluluk çalışmalarının sonuçlarının ölçülmesini de zorlaştırmaktadır (McWilliams vd., 2006:9).

Kurumsal sosyal sorumluluk genellikle ülkedeki kıtlık ya da gelir dağılımındaki problemleri, çevresel tahribat sorunlarını ve toplumsal dışlanmayı çözebilecek etkisi olan bir sihir gibi değerlendirilmektedir. Sendikalar kurumsal sosyal sorumluluk çalışmalarında gönüllü olmaya vurgu yaparken, sivil toplum kuruluşları özel-kamu ortaklığının faydalarına inanmaktadır. Ayrıca kalite yönetimi, iletişim, finans, insan kaynakları yönetimi ve pazarlama gibi farklı yönetim disiplinleri kurumsal sosyal sorumluluk çalışmalarını kendi amaçlarına ulaşmak için bir araç olarak düşünmektedirler (Marrevijk, 2003:96).

Sosyal sorumluluk uygulamaları, kurumun benimsediği, yürüttüğü ve toplumun refah düzeyini yükseltmek ve iyileştirmek için yapılan faaliyetlerdir. Bu faaliyetler çevreyi koruma ile sosyal konuları destekleyen isteğe bağlı olarak yapılan uygulama ve yatırımlardır. Kurumların yatırım yaptığı toplum başta kurum çalışanları olmak üzere, tedarikçiler, dağıtıcılar, kâr amacı gütmeyenler ve kamu sektör ortaklarının yanı sıra genel toplum üyelerinden oluşmaktadır (Kotler ve Lee, 2006:201).

Kurumlar toplumun ihtiyaç ve isteklerini karşılayacak ve onların yararına olacak ürün ve hizmetleri desteklediklerinde toplumdan faaliyetleri ile ilgili onay almaktadırlar. Toplum, kurumlardan isteklerini karşılayabilmesini, istihdam yaratmasını, bağışlar yapmasını ve kârını etkili bir şekilde kullanmasını beklemektedir (Cadbury, 2006:12).

Kurumsal sosyal sorumluluk uygulamalarının başlamasında 1960'larda Amerika'da ortaya çıkan sivil haklar, kadın hakları, müşteri hakları ve çevresel hareketlerin yoğun bir şekilde yaşanması etkili olmuştur. Bu olaylar toplumda iş dünyasının bu konularda bir şeyler yapması gerektiği şeklinde bir algıyı da beraberinde getirmiştir. Bu algı ile oluşan baskı ile birlikte kurumlarda sosyal sorumluluk politikaları, davranışları ve uygulamaları hızlı ve gelişen bir şekilde başlamıştır (Carroll ve Shabana, 2010:87).

Kurumsal sosyal sorumluluk (KSS) ortaklarla ilişkilerde ortaya çıkan sorunları çözmekten yeni ürünler geliştirmeye, çevreye, insan sağlığına ve çalışanların iş güvenliğini karşılayacak ürünler üretmeye, çalışan ilişkileri oluşturmaya, toplumla ve sivil toplum kuruluşları ile işbirliği yapmaya, kurum değerleri ve standartlarına uygun olarak iletişim kurmaya ve kurumun çevresel ve toplumsal bağlılıkları üzerine raporlar yayınlamaya kadar bir çok alanı kapsamaktadır (Verdeyen vd., 2004:326).

Her ne kadar KSS'nin tanımı kurumların eylem ve politikalarına işaret etse de bu eylem ve politikalar farklı aktörlerden etkilenmektedir (Auginis ve Glavas, 2012:933). Özellikle sivil toplum kuruluşları, kurumları daha fazla sorumlu davranmak ve bunun istikrarlı olması yönünde şirketleri etkilemektedirler (Marrevijk, 2003:98). 


\subsection{Paydaşlar ve Kurumsal Sosyal Sorumluluk}

\section{(Stakeholders and Corporate Social Responsibilty)}

Paydaşlar, hisse sahipleri, çalışanlar, müşteriler, baskı grupları, sivil toplum kuruluşları gibi kurumun faaliyetlerinden etkilenen bireyler ve kurumlar olarak tanımlanmaktadır (Goodjik, 2003:227). Özellikle yatırımcılar, çalışanlar, müşteriler, bayiler, tedarikçiler, toplum, sivil toplum kuruluşları ve devlet literatürde paydaş olarak adı sıkça geçen ve kurumlar tarafından da daha sık anılan paydaş gruplarıdır (Grosser, 2009:290).

KSS tanımına göre sosyal olarak sorumlu olan bir kurumun yaptıklarının kurumla direkt ilgili olan ya da olmayan herkesin üzerinde etkisi olduğu düşünülmektedir. Bu yüzden sosyal sorumluluğa önem veren kurumların paydaş teorine göre yönetilmeleri gerekmektedir (Mohr ve Webb, 2005:122). Çünkü KSS ve paydaş kavramı birbirini desteklemektedir (Valor, 2005:193).

KSS'nın hitap etmesi gereken geniş bir paydaş kitlesi vardır. Çevresel sorumluluk, farklılık, onaylayıcı eylem, şeffalık ve hesap verilebilirlik uygulamaları gibi kavramlar KSS için yeni anlamların yanında geniş bir paydaş kitlesi ile olan ilişkileri de beraberinde getirmektedir (Min-Dong, 2008:62).

Kurumsal sosyal sorumluluk paydaşları yanına çekmeyi amaçlamaktadır, bunun yanında kurumlarla çalışanlar, sosyal ortaklar, devlet kurumları gibi paydaşlar arasında yeni ortaklıkları sağlayacak yol ve yöntemlerin kalitesini arttırmaktadır. Kurumsal sosyal sorumluluk kurumun paydaşlarını kurumun ahlaki ve sosyal olarak sorumlu davrandığına dair etkilemek olarak düşünülmektedir (Verdeyen, vd. 2004:326). Kurumsal ve çevresel değişimlere bağlı olarak KSS kurumlarda yönetimsel bir konu haline gelmiştir bu da KSS'nin sınırlarını genişletmekle birlikte tüm faaliyetlerin kurumun farklı paydaşlarının ilgi alanlarıyla kesişmesine de neden olmaktadır (MinDong, 2008:63).

Yöneticilerin, paydaşların hangi konulara önem verdiklerini nelerin onlar için önemli olduğunu ve kurumun itibarını olumlu ya da olumsuz nasıl etkileyebileceklerini anlamalarına yardımcı olacak uygulamalara yönelmesi gerekmektedir Özellikle yeni paydaş gruplarını anlamak daha zordur. Kurumların bu grupların ilgi alanlarını belirleyebileceği yeni stratejiler geliştirmesi gerekmektedir. Paydaşların amaçları ile paralel amaçlar belirlemek kurumun kendi amaçlarına daha kolay ulaşmasını sağlamaktadır (Jonker ve Foster, 2002:188).

Yönetimlerin farklı paydaş gruplarıyla ilişkiler oluşturması, paydaşlara karşı daha şeffaf davranması, paydaşları karar alma sürecine dâhil etmesi, ortaklık için diyaloğu güçlendirmesi ve tüm paydaşlara karşı hesap verebilir davranmasi gerekmektedir. Bununla birlikte farklı paydaş gruplarına karşı sorumluluk duygusunu oluşturması ve harekete geçirmesi gerekmektedir. Ayrıca tüm grupların kararlara katılımını sağlayacak bir kurumsal yapıyı oluşturmanın yanında farklı paydaşların farklı olan ihtiyaçları arasında dengeyi de sağlaması önemlidir (Goodjik, 2003:225-226).

Paydaş gruplar için kurumlar üzerinde belli bir etkiye sahip olmak memnuniyet verici bir durumdur. Kurumların paydaş grupların isteklerini karşılaması ise bu grupların gücü ile ilgilidir. Paydaş grupların gücü ve çeşitliliği şirketlerin çalışma alanına göre farklılıklar göstermektedir. Bu nedenle paydaş teorisine göre KSS çalışması yapacak şirketlerin etkili bir paydaş analizi yapması gerekmektedir (Clarke ve Gibson, 1999:6). İ̧́ ve dış unsurlarla herhangi bir ilişkisi olmayan kurumların paydaşların değerlerindeki, davranışlarındaki ve tutumlarındaki değişim ve dalgalanmaları 
anlayabilmesi ve karşılık verebilmesi mümkün değildir. Bu yüzden "katılım", "ses", "ortaklık", "işbirliği" ve "bağlılık" gibi kavramlar KSS literatüründe sıklıkla yer almaktadır (Pedersen, 2006:140).

Kurumların paydaşlardan gelen baskıyı onların kurum hakkında algı ve duygularını görmezden gelmeleri mümkün değildir (Goodjik, 2003:227). Sosyal hareketler ve aktivist yatırımcilar sorumlu davranmayan kurumların kimlikleri ile ilgili bilgileri kullanmakta ve bu kurumların davranışlarını değiştirmeleri yönünde ısrar etmektedirler (Min-Dong, 2008:66).

Kurumların üzerindeki sosyal baskının iki önemli avantajı vardır; Bunlardan ilki; paydaşların kurumların ekonomik kararlarındaki baskılarıdır. Kurumlar paydaşları ile daha çok sosyal ve çevresel gündemlerini paylaşmaktadır ancak ekonomik kararlarına da paydaşlarını dâhil etmeleri önemlidir. Paydaşlar kurumların ekonomik kararlarında ahlaki değerlere uygun olarak davranmaları konusunda kurumlarla iş birliği yapmaktadır. Ayrıca paydaşlar, kurumların sosyal ve çevresel konulardaki performansları ile neyi hedeflediklerini açıkça görmek isterken; yöneticiler kurumlarının kârlarını topluma faydalı işler yapmak için harcama konusundaki gönülsüzlüklerini ortaya koymaktadırlar (Valor, 2005:205).

\subsection{Paydaş Olarak Kadın (Women as Stakeholder)}

Kadınlar müşteri, paydaş, tedarikçi, tedarik halkası çalışanı ve toplumun bir üyesi olarak kurumların paydaşlarıdır. Kadınlar, kurumların davranışları ile etkilemeye çalıştıkları toplumun nüfusunun yarısını oluşturmaktadırlar. İster sosyal adaletten, ister paydaş, isterse işletme perspektifinden olsun KSS cinsiyet eşitliği konularına değinmek durumundadır (Grooser ve Moon, 2004:20). Cinsiyet eşitliğinin kurumla paydaşlarının isteklerinin entegre edildiği bir modele ihtiyacı vardır. İhtiyaçların belirlenmesi ile ilgili olarak paydaş diyaloğu ve sürekli yapılan izleme ve kontroller farklı paydaşların ihtiyaçlarının belirlenmesinde önemlidir (www.isoe.de).

Grosser'a (2009:290) göre 1957 Roma sözleşmesi ile birlikte kadın ve erkeklerin eşit iş ve eşit ücret hakkı olduğunun belirtilmesinden sonra Avrupa Birliği politikaları cinsiyet ayrımcılığı özelıikle de iş -yaşam dengesi, erkekler kadar kadınların da kararlara katılım hakkı kadınlara karşı şiddetle mücadele ve ürün ve hizmetlerden eşit olarak yararlanmayı kapsayan konularda iş yerinde cinsiyet ayrımcılığı ile ilgili politikalar oluşturmuştur.

Avrupa Birliği'nin raporunda da KSS politikalarında, işletmelerin inovasyonu esas alarak toplumsal faydayı desteklemesi gerektiği üzerinde durulmuştur. İnovasyonun daha iyi ve arkadaşça bir iş ortamı ile toplumsal cinsiyet eşitliğini amaçlandığına değinilmiştir (http://trade.ec.europa.eu, 2006:9). KSS raporlarında kadından bahsedilmesi cinsiyet eşitliği sürecinin kuruluşlar tarafından izlenmesine imkân vermektedir (Vilke vd., 2014:201).

Dünyanın farklı yerlerinde şirketler KSS'ye farklı yaklaşmaktadırlar. Hindistan gibi gelişmekte olan ülkelerde KSS birçok şirket için toplum temelli gelişimin etrafında dönmektedir. Bunlardan çoğu kadınların ekonomik ve sosyal olarak güçlendirilmesi için çalışmaktadır (Abraham, 2013:2). Uluslararası şirketıer de gelişmekte olan ülkelerdeki kadınlar için farklı KSS çalışmaları yürütmektedirler. Coca Cola 5by20 kampanyası ile 2020'ye kadar 5 milyon kadını değer zinciri ile iş sahibi yapmayı amaçlamaktadır. Coca Cola bu projesi için hükümetlerle, sivil toplum kuruluşları ile ve diğer şirketlerle iş birliği yapmaktadır. Coca Cola kadınların iş dünyasında karşılaşacakları sorunları çözmek ve daha sağlam adımlar 
atmalarını sağlamak için eğitimler, finansal destek ve danışmanlık hizmeti vermektedir (http://www.coca-colacompany.com).

Kadınlar güvenlerinin, yeteneklerinin ve davranışlarının geliştirilmesine ve yaptıkları işlerde başarılı olmaya ihtiyaç duymaktadırlar. Kadınların sahip oldukları haklarının farkında olmaları gerekmektedir ve özellikle iş dünyasında cinsiyetlerinden dolayı karşılaşabilecekleri sorunlarla ve anlaşmazlıklarla nasıl mücadele edeceklerini konusunda eğitilmeleri gerekmektedir. Kuruluşların KSS'nin bir parçası olarak kadınlar için farkındalık eğitimleri planlaması gerekmektedir (Kaur, 201339).

Kadınların iş dünyasına kazandırılmasının yanında kadınlarla ilgili yapılan bir diğer önemli çalışma ise; "Body Shop" şirketinin yaptığı çalışmadır. Şirket 2004 yılında çocuk ve kadınlara uygulanan aile içi şiddete dikkat çekmek ve şiddet görenlere destek olmak amacıyla bağış toplamıştır (Welford, http://www.csr-asia.com) .

Cinsiyet konularının özel ya da kamu kurumlarının KSS planlarında yer alıp almadığı soruları daha sık sorulmaya başlanmıştır. Toplumsal cinsiyetin politik boyutları kadınların karar alma sürecine daha fazla katılmalarını sağlamakta ve kadınların önündeki cinsiyete dayalı engelleri azaltmaktadır. Bu durum aynı zamanda KSS içindeki bir diğer konu olan paydaş ilişkilerine de yansımaktadır. Kurumların KSS çalışmalarının bir parçası olarak cinsiyet dengesini sağlamaya yönelik olarak kadınlara çalışan, müşteri ve toplumun bir ferdi olarak neler yaptıkları sorularını da gündeme getirmektedir (Grooser ve Moon, 2004:2). Cinsiyet eşitliğini sağlamak için kadın ve erkeğin eşit olmasını engelleyen şartların ortaya konulması gerekmektedir. UNECE (United Nations Economic Commission for Europe) kadınlar için dezavantajlı olan ve üyelerinin politikalar geliştirebileceği farklı alanlar belirlemiştir. Bu alanlar; kaynaklara ulaşım, iş yerinde eşitsizlik, girişimcilik ve iş ve özel hayat sorumlulukları arasında denge sağlamaktır (http://www.unece.org).

Son zamanlarda birçok kişi ve kuruluş kurumlarında kadınların fayda sağlayacağı faaliyetlerle ilgilendiklerini göstermeye başlamıştır. Yatırımcıların birçoğu yatırım kararlarını kendileri için yeni fırsatlar ortaya çıkaran, sistemdeki tıkanıklıkları tanımlayan ve daha önce keşfedilmemiş değerlerin bulunmasını sağlayan kadın bakış açısıyla uygulamaya başlamışlardır (Weseley, http://ssir.org/).

Kadınlara yönelik olarak yapılan KSS çalışmalarının nasıl olduğu sorusunun yanında kadın yöneticilerin olduğu şirketlerde KSS çalışmalarının nasıl olduğu araştırılmıştır. Bu araştırmaya göre kadın yöneticilerin olduğu şirketlerde KSS çalışmalarının daha az bütçe ile yapıldığı ve erkek yöneticilerin olduğu şirketlere göre çalışmalardan daha olumlu sonuçlar alındığı sonucuna ulaşılmıştır (Soares vd., 2011:1). Kadınların iş dünyasında daha fazla yer alması ülke ve kuruluşlar için verimliliğin artmasıyla yakından ilgilidir (Vilke vd., 2014:201).

Özmutaf ve diğ. (2009) TOBB'un 2007 yllı için ilan ettiği ilk 100 işletmede, yöneticilerin, sosyal sorumluluk faaliyetlerinde konuların belirlenmesi ile ilgili düşünceleri ve bu faaliyetlerle işletmenin imajı arasındaki ilişkinin belirlenebilmesi için anket yönteminden yararlanmışlardır. Bu araştırma sonucunda en başarılı 100 işletme yöneticilerinin sosyal sorumluluk aktivitelerinde konu belirlemesinde hassas bir şekilde davranılması gerektiği, yapılacak sosyal sorumluluk aktivitelerinin işletme imajını olumlu etkilediği ve son olarak sosyal sorumluluk aktivitelerinde konu belirlenirken özellikle kurum felsefesine uygunluğunun özenle değerlendirilmesi gerektiği ifade edilmektedir. Bu çalışmada, literatürde sunulan sosyal sorumluluk, 
paydaş olarak kadın ve kadın sosyal sorumluluğuna web sayfalarından ayrılan yer araştırma konusunu oluşturur. Brand Finance tarafından belirlenen "2015 yılı Türkiye ve Amerika En Değerli Markalar"ı örneklem olarak seçilmiştir. Brand Finance 2015 yılıık raporuna göre en değerli 100 Türk markası ile en değerli 100 Amerikan markası seçilerek, bu kuruluşların kurumsal web sayfaları, kadın sosyal sorumluluğu ile ilgili mesajları içerik çözümleme yöntemine tabi tutularak değerlendirilmiştir. Türk ve Amerikan markalarının kadın sosyal sorumluluğuna verdikleri önem web sayfası kullanımları üzerinden karşılaştırılarak değerlendirecektir.

- Araştırma Sorusu 1: Brand Finance 2015 raporuna göre en değerli Türk ve Amerikan markaları web sayfaları üzerinden kadın sosyal sorumluluğu ile ilgili çalışmalara yer vermekte midir?

- Araştırma Sorusu 2: En değerli Türk markaları ve Amerikan markalarının web sayfalarında kadın sosyal sorumluluğuna ilişkin bilgiler nerede yer almaktadır?

- Araştırma Sorusu 3: En değerli Türk markaları ve Amerikan markalarının web sayfalarında kadın sosyal sorumluluğuna ilişkin mesajların iletilme biçimi nedir?

- Araştırma Sorusu 4: En değerli Türk markaları ve Amerikan markalarının kadın sosyal sorumluluğu mesajları daha çok hangi alanla ilgilidir?

\section{YÖNTEM (METHOD)}

Dünyada ve ülkemizde birçok kuruluş sosyal sorumluluk çalışmaları yaparak hedef kitlelerine bu çalışmalarını çeşitli şekillerde duyurmaktadırlar. Yeni iletişim teknolojilerinin giderek artan kullanımı, kurumlar için cazip alanlar haline gelmiştir. Hedef kitleye en kolay yoldan ulaşmayı sağlayan web sayfalarında kuruluşların sosyal sorumluluk faaliyetlerine ne kadar yer verdikleri, hangi alanlarda sosyal sorumluluk yaptıkları ve ana sayfadan yapılan sosyal sorumluluğuna ulaşılma kolaylığı, bunların yanı sıra mesajların sunulacağı iletişim biçimi araştırmaya değerdir. Bu çalışmada içerik çözümlemesi kullanılmıştır. İçerik çözümlemesinin amacı ise, sınıflandırma sisteminin dayandığı kategorilerin mevcut olup olmadığını göstermenin ötesinde, bunların hangi anlama geldiği ve genel görünüm için hangi ağırlığa sahip olduğunu ortaya koymaktır. Yine sınıflandırma sistemi sonuçta kategorileri karşılaştırabilir ve ölçebilir hale getirme amacını da gütmektedir (Gökçe, 2001:157) .

$\mathrm{Bu}$ anlamda üzerinde durulması gereken önemli bir nokta, kategorilerin kuramsal ve uygulama birikimleri sonucunda önceden oluşturulması gerekliliğidir. Teorik bölümlerde ele alınan konular ışı̆̆ında çalışmada ortaya çıkan araştırma sorularını yanıtlamaya yönelik anlamlı bulgular elde edilip, sınıflandırmaya gidilerek bu amaçla içerik çözümlemesi kodlama cetveli oluşturulmuştur. Kodlama cetvelinin oluşturulma amacı, sınıflandırma sisteminin metine nasıl uygulanacağı, hangi bilgilerin hangi kategorisi içerinde nasıl kodlanacağı yönünde standart bir ölçü kullanılması için açık ve ayrıntılı bilgi sunmaktadır. Çünkü bir araştırmanın güvenilirliğinin temeli buraya dayanmaktadır (Gökçe, 2001:172).

2015 yılı en değerli Türk markaları ve Amerikan markalarının kadın sosyal sorumluluğu ile ilgili uygulamaları; bu uygulamaların markaların kurumsal web sayfalarından nasıl sunulduğunu belirlemek amacıyla Brand Finance tarafindan 2015 yılında sunulan raporda ilan edilen 100 Türk markası ve 100 Amerikan markası ele alınmıştır. Brand Finance tarafından belirlenen 2015 yılı en değerli markalar arasından 100 Türk markası ve 100 Amerikan markası seçilerek, kodlama cetveli oluşturulmuş bu doğrultuda araştırma verileri elde edilmiştir. Çevre 
sosyal sorumluluğuna dair mesajların, kurumların web sayfalarında nerede ve nasıl sunulduğuna ilişkin verilerin toplanmasında Kalender ve Bakan'ın (2006:565) çalışmalarında yer alan kategorilerden yararlanılmıştır. Çalışmada mesajların nerede sunulduğuna dair sınıflama; ana sayfada söz konusu sosyal sorumluluğun başlığı altında link", sosyal sorumluluk linkinde alt başlık", "sosyal sorumluluk ile ilgili dış siteye link", "başka başlık altında link" ve "söz konusu konu ve sosyal sorumlulukla ilgili link yok" olarak belirlenmiştir.

Yine kadın sosyal sorumluluğuna ilişkin mesajların hangi iletişim biçimiyle sunulduğuna dair kategoriler belirlenirken Kalender ve Bakan'ın (2006:565) çalışmalarında kullandığı kategoriler; metinler, raporlar, broşür, kuruluş yayını, sesli ve görüntülü materyaller ve mektup olarak ele alınmaktadır. Tarhan'ın (2011) 100 Sanayi kuruluşunun çevre sosyal sorumluluğuna dair yaptığı incelemede de bu kategorilerden yola çıkarak, "metin", "rapor/yılıık rapor", basın bülteni", konuşma metni", "broşür", kuruluş yayını", sesli ve görsel materyaller" ve "mektup" olarak değerlendirilmiştir. Bu çalışmada örneklem ve kategoriler belirlendikten sonra 100 Türk markası ve 100 Amerikan markasının web sayfalarında kadın sosyal sorumluluğuna ilişkin mesajlara yer verip vermedikleri, mesajları iletme biçimleri ve kadın sosyal sorumluluğunda en fazla sosyal sorumluluk yapılan alana dair veriler değerlendirilerek kodlama işlemi gerçekleştirilmiştir.

\section{BULGULAR (FINDINGS)}

Brand Finance tarafından belirlenen 2015 yılı 100 Türk markası ve 100 Amerikan markası olarak belirlenen kuruluşların sektörlere göre dağılımları, web sayfalarında kadın sosyal sorumluluğuna ilişkin mesajların yer aldığı linkler, kadın sosyal sorumluluğuna ilişkin mesajlar ve bu mesajların iletilme biçimleri de sunulmaktadır. Ayrıca 100 Türk markası ve 100 Amerikan markasının web sayfalarında sundukları bu veriler iki ülke bazında karşılaştırmalı olarak değerlendirilmektedir. Bu veriler ışığında Türkiye ve Amerika arasındaki kullanım farklılıkları ve kadın sosyal sorumluluğuna verilen önem de karşılaştırılarak değerlendirilmektedir.

\subsection{Türk ve Amerikan Markalarının Faaliyet Alanları (Activity Areas of Turkish and American Brands)}

Türk ve Amerikan markalarını diğerlerinden ayıran en önemli özelliklerden biri sahip oldukları marka değerleridir. En değerli 100 Türk markası ve 100 Amerikan markası olarak belirlenen örneklem içerisinde yer alan kuruluşlardan Türk markalarının 73'ünün marka değeri 300 milyon doların altında yer alırken; 27'sinin marka değeri ise 300 milyon doların üzerinde yer almaktadır. Amerikan markalarının 48'nin marka değeri 10 milyar doların altında yer alır iken; 51'inin marka değeri 10 milyar doların üzerinde yer almaktadır. Brand Finance'ın 8. kez yayınladığı "Türkiye'nin En Değerli Markaları" listesinde yer alan 100 markanın toplam değeri 34 milyar 383 milyon dolarken; "Amerika'nın En Değerli Markaları" listesinde yer alan 100 markanın toplam değeri ise 1 trilyon 687 milyar 245 milyon dolardır. 
Tablo 1. Türkiye ve Amerika'daki en değerli 100 markanın sektörlere göre dağılımı

(Table 1. Sectoral dispersal of 100 valuable brands in Turkey and America)

\begin{tabular}{|c|c|c|c|c|c|c|}
\hline Faaliyet Yapılan Sektör & $\begin{array}{l}\text { Türk } \\
\text { Firmaları }\end{array}$ & $\begin{array}{c}\text { USA } \\
\text { Firmaları }\end{array}$ & $\begin{array}{l}\text { TR-USA } \\
\text { Firma } \\
\text { Toplam }\end{array}$ & $\begin{array}{c}\text { Türk } \\
\text { KSS } \\
\text { Yapan } \\
\text { Eirma }\end{array}$ & $\begin{array}{c}\text { USA } \\
\text { KSS } \\
\text { Yapan } \\
\text { Firma }\end{array}$ & $\begin{array}{l}\text { TR-USA } \\
\text { KSS } \\
\text { Toplam }\end{array}$ \\
\hline Bankacılık & 16 & 11 & 26 & 1 & 5 & 6 \\
\hline Telekomünikasyon & 2 & 6 & 8 & 2 & 4 & 6 \\
\hline $\begin{array}{l}\text { Enerji/Petrol/Akaryakıt } \\
\text { Perakende/Lpg Ürt. Tem. }\end{array}$ & 3 & 3 & 6 & 1 & 1 & 2 \\
\hline $\begin{array}{l}\text { Gıda/Temel İhtiyaç } \\
\text { Perakende/Catering }\end{array}$ & 16 & 12 & 28 & - & 2 & 2 \\
\hline Moda/Hazır Giyim/Perakende & 3 & 4 & 7 & 1 & 2 & 3 \\
\hline Havayolu & 3 & 2 & 5 & - & 1 & 1 \\
\hline Gazete & 1 & - & 1 & 1 & - & 1 \\
\hline $\begin{array}{l}\text { Dayanıklı Tüketim Ve } \\
\text { Tüketici Elektroniği }\end{array}$ & 3 & - & 3 & - & - & - \\
\hline İçecek & - & 2 & 2 & - & 2 & 2 \\
\hline Alkollü İçecek & 2 & 1 & 3 & - & - & - \\
\hline Cam & 1 & - & 1 & - & - & - \\
\hline Otomotiv/Otomotiv Dağıtım & 8 & 2 & 10 & - & - & - \\
\hline Spor & 4 & & 4 & - & - & - \\
\hline $\begin{array}{l}\text { Teknoloji/Teknoloji } \\
\text { Perakende /Bilgi İletişim } \\
\text { Tek. }\end{array}$ & 3 & 23 & 25 & - & 5 & 5 \\
\hline İnşaat/Havaalanı İşletme & 1 & - & 1 & - & - & - \\
\hline Sigorta & 5 & 2 & 7 & - & 1 & 1 \\
\hline $\begin{array}{l}\text { Finansal Servis/Ticari } \\
\text { Hizmetler }\end{array}$ & - & 4 & 4 & - & 1 & 1 \\
\hline Sağlık Ve Sağlık Ürünleri & 1 & 4 & 5 & - & 2 & 2 \\
\hline Oto Lastik & 3 & - & 3 & - & - & - \\
\hline $\begin{array}{l}\text { Savunma } \\
\text { Teknoloji/Havacılık }\end{array}$ & 1 & 2 & 3 & - & 1 & 1 \\
\hline Ev Geliştirme Perakende & 1 & 1 & 2 & - & 1 & 1 \\
\hline Cam Eşya Perakende & 1 & - & 1 & - & - & - \\
\hline Turizm & 1 & - & 1 & - & - & - \\
\hline İnşaat Malzemesi & 5 & - & 5 & - & - & - \\
\hline Tekstil & 1 & - & 1 & - & - & - \\
\hline Ev Mobilya & 1 & - & 1 & - & - & - \\
\hline Telekomünikasyon Alt Yapı & 1 & - & 1 & - & - & - \\
\hline Oto Yedek Parça & 1 & - & 1 & - & - & - \\
\hline $\begin{array}{l}\text { Gayrimenkul Yatırım } \\
\text { Ortaklığı }\end{array}$ & 2 & - & 2 & - & - & - \\
\hline Yer Hizmetleri & 1 & - & 1 & - & - & - \\
\hline Finans & 1 & - & 1 & 1 & - & 1 \\
\hline Kırtasiye & 1 & - & 1 & - & - & - \\
\hline Lojistik/Taşımacılık/Kargo & 2 & 3 & 5 & - & - & - \\
\hline Kuyumculuk & 1 & - & 1 & - & - & - \\
\hline Yazılım & 1 & - & 1 & - & - & - \\
\hline Muhtelif & 1 & - & 1 & - & - & - \\
\hline Plastik Doğrama & 2 & - & 2 & - & - & - \\
\hline Medya & - & 11 & 10 & - & 4 & 4 \\
\hline Tütün & - & 1 & 1 & - & - & - \\
\hline Kozmetik/Kişisel Bakım & - & 4 & 4 & - & - & - \\
\hline Makine/Teçhizat & - & 1 & 1 & - & - & - \\
\hline Kimya & - & 1 & 1 & - & - & - \\
\hline Toplam & 100 & 100 & 200 & 7 & 32 & 39 \\
\hline
\end{tabular}




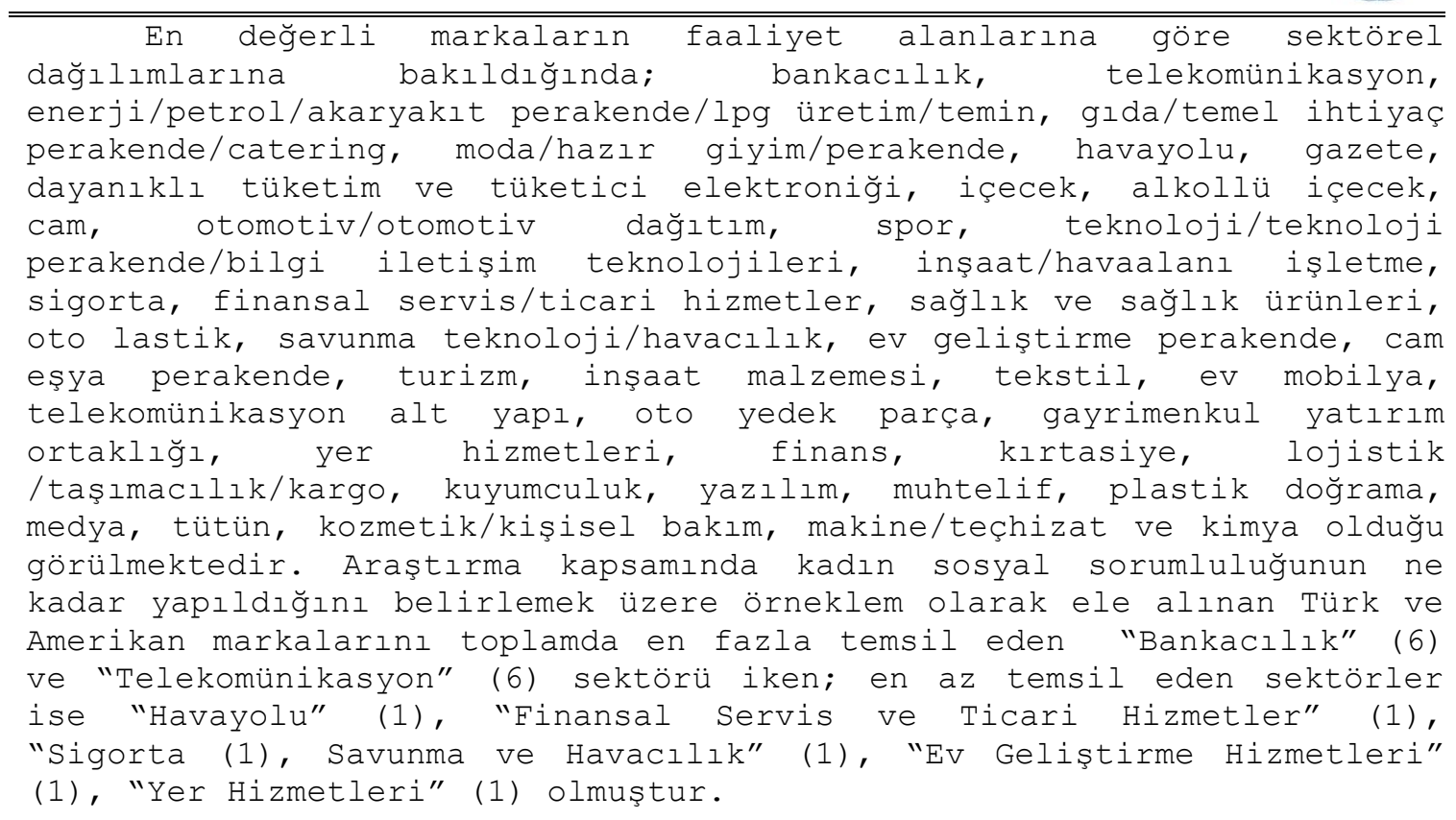

\subsection{Web Sayfalarında Kadın Sosyal Sorumluluğu Linkleri (Women Social Responsibility Links on Web Pages)}

Brand Finance 2015 yılı en değerli Türk ve Amerika markalarının kadın sosyal sorumluluğuna verdikleri önem web sayfalarında yer alış şekli ile ilgili bilgi verebilir. Ana sayfada doğrudan kadın sosyal sorumluluğuna ilişkin verilen link bulunmaması en değerli marka raporunda yer alan markaların bu sosyal sorumluluk türüne çok da önem vermediklerinin değerlendirmesi olabilir.

Tablo 2. Türkiye ve Amerika'daki en değerli 100 markanın web sayfalarında yer alan kadın sosyal sorumluluğu linkleri

(Table 2. Women social responsibility links on web pages of 100 valuable brands in Turkey and America)

\begin{tabular}{|l|c|c|c|c|}
\hline $\begin{array}{l}\text { Kadın Sosyal Sorumluluğu } \\
\text { İe İgili Linkler }\end{array}$ & $\begin{array}{c}\text { Türk } \\
\text { Markaları } \\
\text { KSS Yok }\end{array}$ & $\begin{array}{c}\text { Türk } \\
\text { Markaları } \\
\text { KSS Var }\end{array}$ & $\begin{array}{c}\text { ABD } \\
\text { Markaları } \\
\text { KSS Yok }\end{array}$ & $\begin{array}{c}\text { Markaları } \\
\text { KSS Var }\end{array}$ \\
\hline $\begin{array}{l}\text { Ana Sayfada Kadın Sosyal } \\
\text { Sorumluluğu İle İlili } \\
\text { Doğrundan Link }\end{array}$ & 93 & - & 68 & - \\
\hline $\begin{array}{l}\text { Sosyal Sorumluluk } \\
\text { Linkinde Alt Başlık }\end{array}$ & - & 4 & - & 7 \\
\hline $\begin{array}{l}\text { Sosyal Sorumlulukla } \\
\text { İgili Dış Siteye Link }\end{array}$ & - & - & - & 1 \\
\hline $\begin{array}{l}\text { Başka Başlık Altında } \\
\text { Link }\end{array}$ & - & 3 & - & 24 \\
\hline Toplam & 93 & 7 & 68 & 32 \\
\hline
\end{tabular}

Kadın sosyal sorumluluğu ile ilgili bilgilerin yer aldığı linklerin dağılımı şu şekildedir: Ana sayfada kadın sosyal sorumluluğu ile ilgili doğrudan link sağlayan Türk ve Amerikan markalarının web sayfalarında rastlanmamıştır. Sosyal Sorumluluk Linkinde Alt Başlık şeklinde yer verilen kadın sosyal sorumluluğu konusu Türk markalarının 4'ünde yer alırken; Amerikan markalarında ise 7'sinin web sayfasında yer almaktadır. Örneklem dâhilinde belirlenen markalar, kadın sosyal sorumluluğuna ilişkin bilgileri doğrudan ana sayfada ya da sosyal sorumluluk linki altında paylaşmak yerine başka başlıklar altında da 
paylaşmayı tercih ettikleri gözlemlenmektedir. Türk markaları yapılan sosyal sorumluluğun 3'ünü başka başlıklar altında paylaşırken; Amerikan markalarının ise 24 'ü başka başlıklar altında paylaşmaktadır. En değerli 100 markanın web sayfalarında kadın sosyal sorumluluğuna ya da sosyal sorumlulukla ilgili linklere yer vermeyişi kadın konusuna yeteri kadar önem vermediğinin sonucu olarak değerlendirilebilir. Kuruluşların kadın sosyal sorumluluğuna ilişkin bilgilerine web sayfalarında yer vermelerine bakıldığında; Türk markalarının 93'nin web sayfasında link yer almazken; Amerikan markalarının 68'nin web sayfasında yer verilmemektedir. Çevre, sağlık, eğitim alanında daha fazla sosyal sorumluluk yapılmasına rağmen kadınlara ilgili sosyal sorumluluk faaliyetlerine çok fazla yer verilmediği dikkat çekmektedir.

\subsection{Markaların Web Sayfalarında Kadın Sosyal Sorumluluğu Mesajlarl (Messages of Women Social Responsibility on Web Pages of Brands)}

Araştırma kapsamında değerlendirdiğimiz "Brand Finance En Değerli 100 Türk ve 100 Amerikan Markası" web sayfaları incelendiğinde 93 Türk markasının ve 68 Amerikan markasının sayfasında kadın sosyal sorumluluğu ile ilgili bilgilere rastlanmamıştır.

Tablo 3. Türkiye ve Amerika'daki en değerli 100 markanın web sayfalarında yer alan kadın sosyal sorumluluğu mesajları

(Table 3. Messages of women social responsibility on web pages of 100 valuable brands in Turkey and America)

\begin{tabular}{|l|c|c|c|c|}
\hline $\begin{array}{l}\text { Kadın Sosyal } \\
\text { Sorumluluğu } \\
\text { Mesajları }\end{array}$ & $\begin{array}{c}\text { Türk } \\
\text { Markaları } \\
\text { KSS Mesaj } \\
\text { Yok }\end{array}$ & $\begin{array}{c}\text { Türk } \\
\text { Markaları } \\
\text { KSS Mesaj } \\
\text { Var }\end{array}$ & $\begin{array}{c}\text { ABD } \\
\text { Karkaları } \\
\text { KSS Maj } \\
\text { Yok }\end{array}$ & $\begin{array}{c}\text { Markaları } \\
\text { KSS Mesaj } \\
\text { Var }\end{array}$ \\
\hline Eğitim & - & 1 & - & 9 \\
\hline Şiddet & - & 1 & - & 1 \\
\hline Girişimcilik/Ekonomi & - & 3 & - & 17 \\
\hline Spor & - & - & - & - \\
\hline Parlamentoda Eşitlik & - & 1 & - & - \\
\hline İ̧̧e Eşitlik & - & 1 & - & 5 \\
\hline Sağlık & - & - & - & 1 \\
\hline Hepsi & - & - & - & 32 \\
\hline Toplam & 93 & 7 & 68 & \\
\hline
\end{tabular}

En iyi markaların kadın sosyal sorumluluğu ile ilgili web sayfalarından ilettikleri mesajların içeriği; eğitim, şiddet, girişimcilik/ekonomi, spor, parlamentoda eşitlik, işte eşitlik, sağlık ve tüm maddeleri içeren mesajlardan oluşmaktadır. Türk markalarının 93'ü web sayfalarında kadın sosyal sorumluluğuna ilişkin herhangi bir mesaja yer vermezken; Amerikan markalarının ise 68'nin web sayfalarında kadın sosyal sorumluluğuna ilişkin mesajlara rastlanamamaktadır. En değerli markaların kadınları girişimcilik/ekonomi alanında daha fazla desteklendiği dikkat çekmektedir. Günümüzde kadınların desteklenmeye ihtiyacı olduğu alanlarda kuruluşlar tarafından sosyal sorumluluk faaliyetleri ile bu alanlara destek sağlanmaya çalışıldığı ifade edilebilir. Türk markaların spor ve sağlık mesajları dışında diğer konularda az da olsa mesajlara yer verildiği ifade edilebilir. Ancak kadınlarla ilgili sosyal sorumluluk faaliyetlerine yeterince önem verildiğini söylemek oldukça güçtür. Amerikan markalarının özellikle girişimcilik, eğitim ve sağlık alanında daha fazla sosyal sorumluluk mesajlarına yer verdiği gözlemlenmektedir. Şiddet ve tüm alanları kapsayan mesajlara 
daha az yer verildiği gözlenmektedir. Aynı zamanda Amerikan markalarının spor, parlamentoda eşitlik, işte eşitlik konularında ise mesajlarına rastlanmamaktadır.

\subsection{Web Sayfalarında Kadın Sosyal Sorumluluğu Mesajlarının İletilme Şekilleri (Messages Transmitted Formats of Women Social Responsibility On Web Pages)}

En değerli 100 Türk markası ve 100 Amerikan markasının yaptıkları kadın sosyal sorumluluğuna ilişkin mesajları hedef kitlelere nasıl ulaştırdığı değerlendirildiğinde; Türk markalarının 4'nün metin olarak, 1'nin ylllık rapor olarak, 2'sinin ise görsel ve işitsel materyal olarak ilettiği gözlemlenmektedir. Amerikan markalarının 7'sinin metin olarak, 13'nün ylllık rapor olarak, 11'nin görsel ve işitsel materyal, 1'ni broşür olarak iletmektedirler. Kadın sosyal sorumluluğuyla ilgili mesajların iletilmesinde basın bülteni, kuruluş yayını ve mektup hiç kullanılmamıştır.

Tablo 4. Türkiye ve Amerika'daki en değerli 100 markanın web sayfalarında yer alan kadın sosyal sorumluluğu mesajları iletilme şekilleri

(Table 4. Messages transmitted formats of women social responsibility on web pages of 100 valuable brands in Turkey and America)

\begin{tabular}{|c|c|c|c|c|}
\hline $\begin{array}{l}\text { KSS } \\
\text { Mesajlarının } \\
\text { İletilme } \\
\text { Biçimleri }\end{array}$ & $\begin{array}{l}\text { Türk } \\
\text { Markalarının } \\
\text { Mesaj } \\
\text { Biçimleri Yok }\end{array}$ & $\begin{array}{l}\text { Türk } \\
\text { Markalarının } \\
\text { Mesaj } \\
\text { Biçimleri Var }\end{array}$ & $\begin{array}{c}\text { ABD } \\
\text { Markalarının } \\
\text { Mesaj } \\
\text { Biçimleri Yok }\end{array}$ & $\begin{array}{c}\text { ABD } \\
\text { Markalarının } \\
\text { Mesaj } \\
\text { Biçimleri Var }\end{array}$ \\
\hline Metin & - & 4 & - & 7 \\
\hline Basın Bülteni & - & - & - & - \\
\hline Kuruluş Yayını & - & - & - & - \\
\hline Yıllık Rapor & - & 1 & - & 13 \\
\hline $\begin{array}{l}\text { Görsel ve } \\
\text { İşitsel } \\
\text { Materyaller }\end{array}$ & - & 2 & - & 11 \\
\hline Broşür & - & - & - & 1 \\
\hline Mektup & - & - & - & - \\
\hline Toplam & 93 & 7 & 68 & 32 \\
\hline
\end{tabular}

Kuruluşlar, kadın sosyal sorumluluğuyla ilişkili mesajlarını hedef kitlelerine iletirken görsel ve işitsel materyalleri yeteri kadar kullanmamaktadırlar. Tarhan'ın (2011) çevre sosyal sorumluluğu üzerine yaptığı araştırmasında da görsel işitsel materyallerden yeteri kadar yararlanılmadığı sonucunu ortaya koymaktadır. Bunun sebebi olarak da bilgisayar ve internet hızındaki farklılıkların zaman alması ve hedef kitlenin bu durumdan hoşnut olmayarak ilgili sayfayı terk edebileceği düşüncesinden kaynaklanabileceği ifade edilmektedir.

\section{TARTIŞMA VE SONUÇ (DISCUSSION AND RESULT)}

İki yönlü simetrik iletişim sağlaması açısından önem taşıyan internet ve web sayfası kullanımı hem kurumların sosyal sorumlulukları hakkında toplumu bilgilendirme hem de hedef kitlelerden geribildirim alabilmek için fırsatlar sunar. Kurumsal iletişim için önem arz eden web sayfaları hedef kitleleri bilgilendirme amacıyla kullanılmaktadır. Kuruluşlar amaçlanan paydaşlara ulaşmak ve yüksek etkileşimi sağlamak amacıyla web sayfalarından yararlanmaktadırlar. Global ve yerel tüm kuruluşlar görünürlük sağlamak, sosyal ve çevresel taahhütlerini yerine getirebilmek adına sosyal sorumluluk faaliyetlerine önem vermektedirler. Toplumsal sorumlulukların farkında olduğunu ispatlamaya çalışan kuruluşlar için yapılan sosyal sorumlulukların duyurulması da ayrı bir önem taşımaktadır. Hedef kitlelerin 
zihinlerinde yer eden kapitalist firma algısı ancak bu faaliyetlerin sıklıkla duyurulması sonucunda farklılık gösterebilir. Bunu duyurmanın en kolay yolu web sayfalarını etkili kullanabilmekten geçer. Çalışma kapsamında en değerli 100 Türk markası ve 100 Amerikan markasının web sayfaları incelendiğinde ise Türk markaların sosyal sorumluluk faaliyetlerine gereken önemi vermediği ifade edilebilir. En değerli 100 marka olarak belirlenen pek çok kuruluşun sosyal sorumluluk yaptığı ancak sosyal sorumluluk yapılan alanların sınırlı olduğu sonucuna ulaşılmaktadır. Kadın sosyal sorumluluğunu içeren çalışmaların çok az olması ya da henüz kadın sosyal sorumluluğun farkına varılmaması bu konuya önem verilmediğini kanıtlar niteliktedir. Oysaki son yıllarda ülkemizde yaşanan kadın cinayetleri, kız çocuklarının okula gönderilmemesi, küçük yaşta evlendirilmeleri, kadın çalışan sayısının azlığı gibi kimi konularda toplumsal sorumluluklarının olduğunu hatırlayan kuruluş sayısı yok denecek kadar azdır.

Değerlendirmelere sonucunda 100 Türk markasından 7'sinin, 100 Amerikan markasından da yalnızca 32'sinin kadın sosyal sorumluluğuna yer verdiği gözlemlenmektedir. Kurumların çevre, eğitim, sağlık vb. gibi alanlarda daha fazla sosyal sorumluluk faaliyetleri yaptıkları gözlemlenmektedir. Araştırmanın çarpıcı sonuçlarından biri Türk ve Amerikan markalarının karşılaştırmalı olarak kadın sosyal sorumluluğuna gereken önemi vermedikleri bulgusudur. Bunun nedenleri arasında halen kadına verilen değerin yeteri kadar anlaşılmadığı ifade edilebilir. Bu sebeple kurumsal sosyal sorumluluk çalışmalarında kadın sosyal sorumluluğuna ayrılan bütçe ve verilen önem kısıtlı olmaktadır. Hedef kitlelere kolay ulaşmanın ve onları daha kolay bilgilendirmenin yollarını açan web sayfaları sosyal sorumluluk faaliyetlerin duyurulmasında da etkilidir.

Kurumların sosyal sorumluluk faaliyetlerine verdikleri önem web sayfalarında yer alma şekliyle de belirlenebilir. Araştırma kapsamında değerlendirilen markaların web sayfalarında kadın sosyal sorumluluğu ile ilgili doğrudan erişim sağlayan bir linke rastlanamamıştır. Yapılan sosyal sorumluluk faaliyetlerine genellikle farklı başlıklar altında ya da kurum hakkında bilgilerin yer aldığı başlıklar altında ulaşabilmektedir. Doğrudan sosyal sorumluluk başlığı altında sunan kurumların sayısı oldukça azdır. Markalar kadın sosyal sorumluluğuna çok önem vermeseler de yaptıkları sosyal sorumluluk faaliyetleri ile ilgili mesajları şu şekilde sıralanmaktadır: Eğitim, şiddet, girişimcilik/ekonomi, spor, parlamentoda eşitlik, işte eşitlik, sağlık. Girişimcilik/ekonomi alanında yapılan sosyal sorumluluk türü Türk ve Amerikan markalarının en fazla önem verdikleri alan olmuştur. Kadının desteklenmesi ve kendi işini kurmasına yardımcı olarak iş hayatında söz sahibi olması amaçlanmaktadır. Destekledikleri kadınlara teknoloji, mühendislik ve diğer alanlarda eğitim sağladıkları gözlemlenmektedir. Çalışmada ulaşılan bir diğer bulgu ise kuruluşların web sayfalarından kadın sosyal sorumluluğuna ilişkin mesajları hedef kitlelerine iletme biçimleridir.

En değerli 100 Türk markasının kadın sosyal sorumluluğuna ilişkin mesajlarını iletmede daha çok metin, görsel-işitsel ve yıllık rapor biçimlerini kullanmaktadırlar. Broşür, basın bülteni ve mektuptan yararlanmadıkları gözlemlenmektedir. En değerli 100 Amerikan markasının kadın sosyal sorumluluğu mesajlarını iletme biçimlerine bakıldığında ise en fazla yıllık rapor, görsel-işitsel, metin ve broşürden yararlanılmaktadır. Amerikan markalarının web sayfalarından kadın sosyal sorumluluğuna ilişkin mesajlarını iletirken basın bülteni, kuruluş yayını ve mektup türlerinden yararlanılmadığı göze çarpmaktadır. Genel olarak Türk ve Amerikan markalarının diğer 
alanlarda yaptıkları sosyal sorumluluk faaliyetleri kadın sosyal sorumluluğundan fazladır. En değerli 100 Türk markasının sosyal sorumluluk faaliyetleri içinde kadın sosyal sorumluluğuna ayırdığı yer dikkat çekicidir. Bu alanda yapılan sosyal sorumluluğun oldukça düşük olması Türkiye'de kadın konusuna verilen değerin yeniden gözden geçirilmesini gerekli kılar. En değerli 100 Amerikan markasının toplam sosyal sorumlulukları içinde kadın sosyal sorumluluğuna ayırdığı yer incelendiğinde ise Türkiye'ye göre daha iyi durumda olduğu gözlemlenmektedir. Ancak Amerikan markalarının global kuruluşlardan oluşması ve değerlendirmeye alınan 100 markadan yalnızca 32'sinde rastlanması da üzerinde düşünülmesini gereken bir konudur. Gerek Türkiye'de gerekse Amerika'da toplumsal alanda kadına verilen değer kuruluşların sosyal sorumluluk faaliyetlerine de yansımıştır. Kadın sosyal sorumluluğuna ayrılan bütçenin ve kadının desteklenmesinin beklenilen düzeyde olmadığı sonucuna ulaşılmıştır. Bunun için kurumların bu alanı desteklemelerinde gerekli yasal ya da kurumsal özendirmelerin teşvik edilmesi yerinde bir davranış olacaktır.

\section{KAYNAKLAR (REFERENCES)}

- Abraham, D.T., (2013). Csr and Empowerment of Women: The Way Forward, AIMA Journal of Management \& Research, February 2013, Volume:7, Issue:1-4, ss:1-14.

- Aguinis, H. and Glavas, A., (2012). What We Know and Don't Know About Corporate Social Responsibility: A Reviewand Research Agenda, Journal of Management, Volume:38, Issue:4, ss:932-968.

- Asongu, J.J., (2007). The History of Corporate Social Responsibility, Journal of Business and Public Policy, Volume:1, Issue:2, ss:1-18.

- Bolton, S.C., Chung-hee, K.R., and O'Gorman, K.D., (2011). Corporate Social Responsibility as a Dynamic Internal Organizational Process: A Case Study, Journal of Business Ethics, Volume:101, ss:61-74.

- Boone, L.E. and Kurtz, D.L., (1992). Management, New York: McGraw-HillBoone and Kurtz.

- Cadbury, A., (2006). Corporate social responsibility, 21st Century Society, Volume:1, Issue:1, ss:5-21.

- Carroll, A., (1991). Pyramid of Corporate Social Responsibility: Toward the Moral Management of Organizational Stakeholders, Business Horizons, Volume:34, Issue:4, ss:39-48.

- Carroll, A.B. and Shabana, M.K., (2010). The Business Case for Corporate Social Responsibility: A Review of Concepts, Research and Practice, International Journal of Management Reviews, ss: 85-105.

- Clark, J. and Gibson, S.M., (1999). The use of corporate disclosures in management of reputation and legitimacy: a cross sectorel analysis of UK top 100 companies, Business Ethics: A European Review, Volume:8, Number:1, ss:5-13.

- Evuleocha, S.U., (2005). Managing Indigenous Relations: Corporate Social Responsibility in a New Age of Activism, Corporate Communications: An International Journal, Volume:10, Number:4, ss:328-340.

- Goodjik, R., (2003). Partnership at corporate level: The meaning of the stakeholder model, Journal of Chance Management, Volume:3, Number:3, ss:225-241.

- Gökçe, O., (2001). İçerik Çözümlemesi; Teori-Metod-Uygulama, Konya: Sel-Ün Yayınları. 
- Grosser, K. ve Moon, J., (2004). Gender Mainstreaming and Corporate Social Responsibility: Reporting Workplace Issues Research Paper Series International Centre for Corporate Social Responsibility. Ed. Dirk Matten, International Centre for Corporate Social Responsibility Nottingham University Business School Nottingham University. Number:27, ICCSR Research Paper Series, ss:1-39.

- Grosser, K., (2009). Corporate social responsibility and gender equality: women asstakeholders and the European Union sustainability strategy, Business Ethics: A European Review, Volume:18, Number:3, ss:290-307.

- Jonker, J. ve David, F., (2002). Stakeholder Excellence? Framing The Evolution and Complexity of a Stakeholder Perspective of the Firm, Corp. Soc. Responsib. Environ. Mgmt 9, Ss : 187-195.

- Kalender, A. ve Bakan, Ö., (2006). Kurumsal Sorumluluğun Web Sayfalarındaki Görünümü: Sanayii Kuruluşlarının Web Sayfaları Üzerine Bir İnceleme, Yeni İletişim Ortamları ve Etkileşim Uluslararası Konferansı, 1-3 Kasım 2006, ss:560-568.

- Kaur, P., (2013). Corporate Social Responsibility and Gender in Workplace, International Journal of Humanities and Social Science Invention, Volume:2, Issue:11, November:2013, ss:36-40.

- Kotler, P. ve Lee, N., (2006). Kurumsal Sosyal Sorumluluk, Çev: Sibel Kaçamak, İstanbul: Mediacat Yayınları.

- Marrevijk, V.M., (2003). Concept and Definations of CSR and Corporate Sustainability: Between Agency and Communion, Journal of Business Ethics, Volume:44, Issue:2-3, ss:95-105.

- Min-Dong, P.L., (2008). A review of the theories of corporate social responsibility: Its evolutionary path and the road ahead. International Journal of Management Reviews, ss:53-73.

- Mohr, L. and Webb, A.D.J., (2005). The Effects of Corporate Social Responsibility and Price on Consumer Responses, The Journal of Consumer Affairs, Vol:39, No:1, ss:121-147.

- Özmutaf, N M., Çelikkol, H. ve Çelikkol M.M., (2009). Yönetici Bakışıyla Sosyal Sorumluluk Aktivitelerinde Konunun Belirlenmesi ve İşletme İmajı: Ampirik Bir Yaklaşım, Dumlupınar Üniversitesi Sosyal Bilimler Enstitüsü Dergisi, Volume:24, Issue:3, ss:233244 .

- Pedersen, E.R., (2006). Making Corporate Social Responsibility (CSR) Operable: How Companies TranslateStakeholder Dialogue into Practice, Business and Society Review, Volume:111, Issue:2, Ss: $137-163$.

- Soares, R., Marquis, C., and Lee, M., (2001). Gender and Corporate Social Responsibility: It's a Matter of Sustainability, Catalayst, 1-4.

- Tarhan, A., (2011). Kurumsal Çevre Sorumluluğu: Sanayi Kuruluşlarının Web Sayfaları Üzerine Bir Değerlendirme, NWSA, Volume:6, Issue:3, ss:539-558.

- Valor, C., (2005). Corporate Social Responsibility and Corporate Citizenship: Towards Corporate Accountability, Business and Society Review, Volume:110, Issue:2, ss:191-212.

- Welford, R., (2005). Domestic violence and CSR, http://WwW. Csrasia.com/. (Erişim tarihi: 20 Ocak 2016).

- Verdeyen, V. and Put, J.B.V., (2004). A social stakeholder model, Int J Soc Welfare, Volume:13, ss:325-331. 
- Wesely, M., (2015). Gender Equity and Corporate Sustainability, http://ssir.org (Erişim tarihi: 20 Ocak 2016).

- Wilke, R., Raisene, A.G., and Simanaviciene, Z., (2014). Gender and corporate social responsibility: 'big wins' for business and society? Procedia-Social and Behavioral Sciences, 156, ss:198202 .

- http://www.unece.org/ (Erişim Tarihi: 18 Ocak 2016).

- http://www.isoe.de/ftp/RARE_Flyer_Gender.pdf (Erişim Tarihi: 19 Ocak 2016).

- http://www.businessdictionary.com (Erişim Tarihi: 21 Ocak 2016).

- http://trade.ec.europa.eu (Erişim Tarihi: 18 Ocak 2016).

- http://www.coca-colacompany.com (Erişim Tarihi: 19 Ocak 2016). 